\title{
Habitat preferences of female humpback whales Megaptera novaeangliae in the Hawaiian Islands are associated with reproductive status
}

\author{
Alison S. Craig*, Louis M. Herman \\ Kewalo Basin Marine Mammal Laboratory, University of Hawaii, 1129 Ala Moana Blvd., Honolulu, Hawaii 96814, USA \\ and \\ The Dolphin Institute, 420 Ward Avenue, Suite 212, Honolulu, Hawaii 96814, USA
}

\begin{abstract}
The main Hawaiian Islands are the primary winter reproductive area for the majority of North Pacific humpback whales Megaptera novaeangliae. Identification photographs of individual whales, including 63 females sighted in at least 2 different years and with at least 1 calf, were collected from waters off the islands of Maui and Hawaii ('Big Island') between 1977 and 1994. Calves formed a significantly larger proportion of the population off Maui than off the Big Island. The overall proportion of calves to all whales identified (crude birth rate) was 0.099 off Maui and 0.061 off the Big Island. Also, considering only females seen in more than 1 year, the number of calves per female per year (calving rate) was 0.71 off Maui and 0.52 off the Big Island. These rates may be inflated somewhat because of the greater likelihood of sighting and identifying females with calf than females without. Females sighted at both Maui and the Big Island in different years were with a calf significantly more often in Maui waters than in Big Island waters. It was concluded that habitat utilisation by females varies between Maui and the Big Island, and appears to depend in part upon reproductive status.
\end{abstract}

KEY WORDS: Humpback whale - Habitat Calving · Reproduction

\section{INTRODUCTION}

The main Hawaiian Islands are the winter reproductive area for the majority of North Pacific humpback whales Megaptera novaeangliae (e.g. Herman 1979, Baker \& Herman 1981, 1987). Mature females are believed to conceive during the winter season on, or en route to, the winter grounds, and return to give birth the following winter after a gestation period of 10 to 12 mo (Chittleborough 1958, 1965, Nishiwaki 1959). Although examinations of commercial whaling catches revealed occasional twin foetuses (Tomilin 1967), no female has ever been documented with more than 1 calf.

Although humpback whales have been studied extensively in Hawaii (e.g. Herman \& Antinoja 1977. Darling \& Morowitz 1986, Glockner-Ferrari \& Ferrari

\footnotetext{
•E-mail: acraig@hawaii.edu
}

1990, Frankel et al. 1995), little is known about habitat utilisation within this region. The majority of humpbacks are found within the $183 \mathrm{~m}$ (100 fathom) isobath (Herman \& Antinoja 1977, Herman et al. 1980, Mobley et al. 1997), and it has been proposed that mother-calf pairs are distributed primarily in nearshore, shallow water (e.g. Herman et al. 1980, Glockner \& Venus 1983, Smultea 1994). Similar findings have been reported for the winter grounds of the North Atlantic (e.g. Whitehead \& Moore 1982, Mattila \& Clapham 1989). Although mother-calf pairs are found throughout the main Hawaiian Islands, there have been suggestions that some areas are favoured over others. Herman et al. (1980) performed aerial and ship-based surveys throughout the main Hawaiian Islands in 1977 and found that calves were much more common in the 4island region of Molokai, Lanai, Maui and Kahoolawe (collectively referred to here simply as 'Maui') than elsewhere. For example, in January and February, $73.6 \%$ of all calves seen were off Maui, whereas only 
$11.3 \%$ were seen off the island of Hawaii (known as the 'Big Island'). Until now, however, there has been no systematic comparison of long-term calving data collected off different Hawaiian islands.

The factors that determine humpback distribution in Hawaii are largely unknown; given the temporal and geographical separation of feeding and reproduction in humpbacks, their distribution in the winter grounds cannot be predicted from the distribution of prey resources. Humpback whales are known to exhibit some temporal segregation in migration to the winter grounds on the basis of age, sex and reproductive status (e.g. Dawbin 1966, Nishiwaki 1966). Baker \& Herman (1981) reported differences in migratory timing for different locations within the Hawaiian Islands: the number of whales peaked relatively early at the Big Island, and progressively later peaks occurred at Maui, Penguin Bank and Oahu. Baker \& Herman (1981) suggested that different locations within Hawail may be used by whales of different age-sex classes or reproductive states, and that the temporal segregation in migration demonstrated by Dawbin (1966) and Nishiwaki (1966) may result in differing patterns of peak abundance in different locations within the Hawaiian breeding range.

Humpback whales can be identified individually by the black-and-white pigmentation and scarring on the ventral surface of the tail flukes, together with the pattern of serrations along the trailing edge (Katona et al. 1979). Photo-identification enables the compilation of individual sighting histories across years and locations. Previous photo-identification studies have calculated crude birth rates by dividing the number of calves identified by the total number of whales including calves (e.g. Clapham \& Mayo 1987, 1990); calving rates were calculated by dividing the number of mature females with calves by the number of mature females with or without calves (e.g. Baker et al. 1987, 1992, Clapham \& Mayo 1987, Perry et al. 1990, Straley 1994). However, none of these studies compared long-term reproductive data collected in more than 1 location within a winter ground.

Baker et al. (1987) calculated calving rates for females observed in Hawailan waters between 1978 and 1984, based on a sample of 38 sightings of 18 females. The present study extends this data set to 150 sightings of 63 females observed between 1977 and 1994. Calving rates are calculated separately for Maui and the Big Island, and the extent to which females, with or without a calf, were observed in each area is examined to determine if habitat use varies with reproductive status. Crude birth rates are calculated separately for Maui and the Big Island using our identifications of all whales (not simply females) between 1977 and 1994 .

\section{METHODS}

The present study utilised fluke photographs and associated data collected in waters off Maui and the Big Island (Fig. 1) by staff of the Kewalo Basin Marine Mammal Laboratory (KBMML) between January and April of each year from 1977 to 1994. Table 1 summarises the data collection effort. Because whale density peaks and diminishes earlier in the season at the Big Island than Maui (Herman et al. 1980, Baker \& Herman 1981), Big Island observations were sometimes discontinued at an earlier date than were observations off Maui.

The whales were followed in small outboard boats and photographed using $35 \mathrm{~mm}$ cameras equipped with telephoto lenses, typically of $300 \mathrm{~mm}$. High-speed, black-and-white film was generally used, although colour slide film was also used occasionally. There was no deliberate selection of particular whales or groups of whales for photography. Whales were typically followed for as long as was necessary to obtain good fluke photographs. The best photograph of each whale's flukes was allocated a unique observation number, and was classified into 1 of 5 categories according to the degree of white pigmentation. Each fluke photograph was compared visually to the others in the same colour category, and those found to match unambiguously were assigned a common 'resight' number (e.g. Perry et al. 1988j. It was thus possible to link together all identifications of a given individual across time.

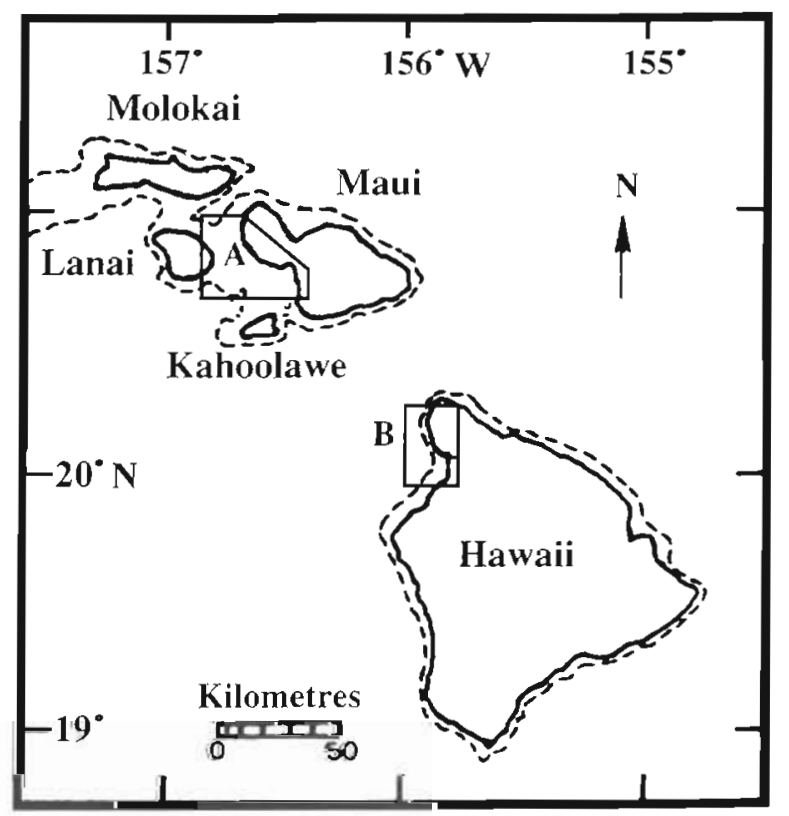

Fig. 1. Map of the study areas: west Maui (Area A) and the northwest Kohala coast of Hawaii ('Big Island') (Area B). Dashed lines represent the $183 \mathrm{~m}$ (100 fathom) isobath 
Table 1. Data collection in Hawaiian waters

\begin{tabular}{|lllc|}
\hline Year & Location & Study period & Effort (total days) \\
\hline 1977 & Maui & 12 Feb-20 Apr & Unknown \\
1978 & Maui & 1 Feb-8 Apr & 40 \\
1979 & Maui & 3 Feb-31 Mar & 37 \\
1980 & Maui & 27 Jan-2 Apr & 44 \\
& Big Island & 15 Jan-5 Apr & 27 \\
1981 & Maui & 11 Jan-12 Apr & 34 \\
& Big Island & 21 Jan-24 Feb & 23 \\
1982 & Maui & 3 Jan-28 Mar & 43 \\
1983 & Maui & 1 Feb-29 Mar & 52 \\
1984 & Maui & 26 Jan-28 Mar & 55 \\
1985 & Maui & 6 Mar-6 Apr & 28 \\
& Big Island & 18 Jan-12 Mar & 32 \\
1986 & Maui & 1 Mar-22 Apr & 39 \\
& Big Island & 19 Jan-27 Feb & 28 \\
1987 & Maui & 23 Jan-12 Apr & 64 \\
1988 & Maui & 17 Mar-16 Apr & 22 \\
& Big Island & 13 Jan-10 Mar & 44 \\
1989 & Big Island & 7 Jan-3 Apr & 63 \\
1990 & Big Island & 11 Jan-13 Apr & 59 \\
1991 & Big Island & 9 Jan-15 Apr & 59 \\
1992 & Big Island & 11 Jan-3 Apr & 42 \\
1993 & Big Island & 15 Jan-7 Apr & 62 \\
1994 & Big Island & 26 Jan-19 Mar & 36 \\
& & & \\
\hline
\end{tabular}

Whales were assumed to be female on the basis of 1 or more identifications with a calf: during each observation, the mother was distinguished by her consistently close proximity to the calf, because there is no reliable method of determining sex from surface observations. It was assumed that all females sighted without a calf in a given year did not produce a calf that year.
All data associated with each fluke photograph were stored in a Statistical Analysis System (SAS) file on the IBM ES/9000 mainframe computer at the University of Hawaii. These data were accessed by means of programs written in the SAS programming language, and SAS was used in the calculation of all statistics.

\section{RESULTS}

\section{Reproductive histories}

Reproductive histories were compiled for 63 females identified in Hawaiian waters in more than 1 year from 1977 to 1994 (see Table 2). Of the 63 females, $34(54.0 \%)$ were identified at both Maui and the Big Island, $18(28.6 \%)$ at Maui only, and 11 (17.5\%) at the Big Island only. No female was identified at both locations within the same year. These 63 females produced a total of 95 calves. Table 2 shows that a calf was present in 63 of $89(70.8 \%)$ Maui records, and in 32 of 61 $(52.5 \%)$ Big Island records (Yates corrected $\chi_{1}{ }^{2}=4.48$, $\mathrm{p}=0.034$ ). When only the 34 females identified in both locations were considered, a calf was present in 35 of $50(70.0 \%)$ Maui records but only 16 of $39(41.0 \%) \mathrm{Big}$ Island records (Yates corrected $\chi_{1}{ }^{2}=6.38, p=0.012$ ).

Of the 29 Big Island records of females without a calf, only 8 featured females who had never been seen with a calf previously. Thus, 21 of the $29(72.4 \%)$ records of females without calves off the Big Island featured females who were known to be sexually mature.

Table 2. Megaptera novaeangliae. Years seen, locations and reproductive status of all females identified in more than 1 year in Hawaii. All years in which a female was accompanied by a calf are underlined (M, Maui; $B$, Big Island)

\begin{tabular}{|c|c|c|c|c|c|}
\hline Whale & Sightings & Whale & Sightings & Whale & Sightings \\
\hline 835 & $77 \mathrm{M} \underline{86 \mathrm{~B}}$ & 354 & 82M $84 \mathrm{M}$ 90B $94 \mathrm{~B}$ & 1241 & $\underline{84 \mathrm{M}} 91 \mathrm{~B}$ \\
\hline 62 & $\underline{78 \mathrm{M}} \underline{81 \mathrm{M}}$ & 432 & $\underline{8 \mathrm{M}} 84 \mathrm{M} 93 \mathrm{~B}$ & 1283 & $\underline{84 \mathrm{M}} \underline{92 \mathrm{~B}}$ \\
\hline 424 & $78 \mathrm{M} 82 \mathrm{M}$ & 830 & $\underline{82 \mathrm{M}} 86 \mathrm{~B}$ & 1338 & $84 \mathrm{M} 93 \mathrm{~B}$ \\
\hline 996 & 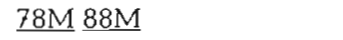 & 1089 & $\underline{82 \mathrm{M}} 84 \mathrm{M} \underline{89 \mathrm{~B}} 91 \mathrm{~B}$ & 494 & $86 \mathrm{M} 87 \mathrm{M}$ \\
\hline 75 & $\underline{79 \mathrm{M}} 81 \mathrm{M} 86 \mathrm{M} 94 \mathrm{~B}$ & 301 & $83 \mathrm{M} 93 \mathrm{~B}$ & 570 & $\underline{8 \mathrm{M}} 87 \mathrm{M} 89 \mathrm{~B}$ \\
\hline 370 & $79 \mathrm{M} 84 \mathrm{M} 88 \mathrm{~B}$ & 344 & 83M 93B & 587 & $86 \mathrm{M} 88 \mathrm{~B} 90 \mathrm{~B}$ \\
\hline 11 & $\underline{80 \mathrm{M}} 83 \mathrm{M}$ & 355 & $83 \mathrm{M} 84 \mathrm{M}$ & 860 & $86 \mathrm{~B} \underline{89 \mathrm{~B}}$ \\
\hline 26 & $80 \mathrm{~B} \underline{86 \mathrm{M}}$ & 442 & $83 \mathrm{M} 84 \mathrm{M}$ & 1041 & $86 \mathrm{M} 88 \mathrm{M}$ \\
\hline 31 & $\underline{80 \mathrm{~B}} 87 \mathrm{M}$ & 499 & $83 \mathrm{M} 85 \mathrm{M} 92 \mathrm{~B}$ & 1119 & $86 \mathrm{M} 89 \mathrm{~B}$ \\
\hline 71 & 80M $81 \mathrm{~B} 82 \mathrm{M} 84 \mathrm{M}$ & 540 & $\underline{83 \mathrm{M}} 84 \mathrm{M}$ & 1216 & $\underline{86 \mathrm{~B}} 91 \mathrm{~B}$ \\
\hline 100 & $80 \mathrm{~B} \underline{83 \mathrm{M}}$ & 599 & $83 \mathrm{M} 88 \mathrm{~B}$ & 1093 & $\underline{87 \mathrm{M}} 88 \mathrm{~B}$ \\
\hline 177 & $81 \mathrm{~B} \underline{84 \mathrm{M}} 94 \mathrm{~B}$ & 846 & $83 \mathrm{M} 86 \mathrm{M}$ & 1012 & $88 \mathrm{M} 90 \mathrm{~B}$ \\
\hline 228 & $81 \mathrm{M} 82 \mathrm{M} 83 \mathrm{M} 84 \mathrm{M} 92 \mathrm{~B}$ & 951 & $83 \mathrm{M} 87 \mathrm{M}$ & 1192 & $\underline{88 \mathrm{~B}} \underline{90 \mathrm{~B}}$ \\
\hline 245 & $81 \mathrm{M} 82 \mathrm{M} 83 \mathrm{M}$ & 954 & $83 \mathrm{M} 87 \mathrm{M} 90 \mathrm{~B}$ & 1056 & $\underline{89 \mathrm{~B}} \overline{90 \mathrm{~B}}$ \\
\hline 535 & $81 \mathrm{M} 87 \mathrm{M} 92 \mathrm{~B} 93 \mathrm{~B}$ & 1074 & $83 \mathrm{M} 89 \mathrm{~B}$ & 1067 & $89 \mathrm{~B} 91 \mathrm{~B}$ \\
\hline 849 & $81 \mathrm{M} 86 \mathrm{M}$ & 359 & $84 \mathrm{M} \underline{92 \mathrm{~B}}$ & 1071 & $\underline{89 B} \underline{93 B}$ \\
\hline 952 & $81 \mathrm{~B} \underline{87 \mathrm{M}}$ & 834 & $84 \mathrm{M} \underline{86 \mathrm{~B}}$ & 481 & $\underline{90 \mathrm{~B}} \underline{93 \mathrm{~B}}$ \\
\hline 1116 & $\underline{81 \mathrm{M}} 89 \mathrm{~B}$ & 851 & $84 \mathrm{M} 86 \mathrm{M}$ & 1223 & $\underline{90 B} 94 \mathrm{~B}$ \\
\hline 1125 & $\underline{81 \mathrm{M}} \underline{89 \mathrm{~B}}$ & 966 & $\underline{84 \mathrm{M}} \overline{87 \mathrm{M}}$ & 1289 & $91 \mathrm{~B} 92 \mathrm{~B}$ \\
\hline 132 & $82 \mathrm{M} 88 \mathrm{M}$ & 967 & $\overline{84 M} 87 \mathrm{M} 93 \mathrm{~B}$ & 1353 & $91 \mathrm{~B} \underline{93 \mathrm{~B}}$ \\
\hline 346 & $\overline{82 \mathrm{M}} \underline{83 \mathrm{M}} \underline{8 \mathrm{M}} \underline{87 \mathrm{M}}$ & 980 & $84 \mathrm{M} 88 \mathrm{M}$ & 1407 & $91 \mathrm{~B} \underline{94 \mathrm{~B}}$ \\
\hline
\end{tabular}


Also, of the 63 females, 38 were identified with a calf in 1 year only, 19 were identified with calves in 2 different years, 5 with calves in 3 different years and 1 with calves in 4 different years. The longest interval between first and last identifications with calf for any female was $15 \mathrm{yr}$ : Whale 75 was first identified with a calf off Maui in 1979, and most recently identified with a calf off the Big Island in 1994. During this interval, she was also identified with a calf off Maui in 1981 and in 1986.

Of the 13 females whose histories included identifications in 2 or more consecutive years, only 1 was identified with a calf in successive years. This is consistent with other data indicating that annual births constitute a minority of interbirth intervals in humpback whales (e.g. Chittleborough 1958, Straley 1994, Barlow \& Clapham 1997).

\section{Calving rates}

If identification histories of females were complete, the mean calving rate (calves per female per year) would be the inverse of the mean calving interval. However, because there are few identifications of females in consecutive years, calving rates must be estimated in a different way. Following the example of Baker et al. (1987) and Clapham \& Mayo (1987), the yearly and overall calving rates were estimated from Table 2 by dividing the number of females with a calf in each year by the total number of females with or without a calf that year. Because the sex of females was determined through identifications with a calf on 1 or more occasion, no whale identified in 1 year only could be considered female unless she was accompanied by a calf. These females were excluded from the calculation so that the calving rate was not artificially inflated.

Table 3 summarises the yearly calving rates, categorised by island region. The total number of females from which each calving rate was calculated is shown in parentheses. Excluding cases where the sample size was 3 or less, annual rates in Maui varied between 0.53 in 1984 and 1.00 in 1986, and annual rates for the Big Island varied between 0.20 in 1988 and 0.80 in 1994 .
The mean of the annual calving rates is not truly representative of the data because of small sample sizes in some years. Considering only those years in which 5 or more females were seen, the mean calving rate for Maui was $0.73(\mathrm{SE}=0.06)$ and the mean calving rate for the Big Island was $0.56(\mathrm{SE}=0.07)$. The overall calving rate, calculated by dividing the total number of females with caives by the total number of females with or without calves, better represents all available data. The overall calving rate was higher for Maui $(0.71)$ than for the Big Island (0.52). As described earlier, this geographical difference in the number of calves per female was significant. When all data from both locations were combined, the overall calving rate was 0.63 .

\section{Crude birth rates}

The crude birth rate was calculated for each year and location by dividing the total number of calves by the total number of individual whales (including calves) identified in that year and location (Clapham \& Mayo 1987). Because young calves rarely reveal their flukes above water in the winter grounds, and because the pigmentation patterns on the flukes of young calves are still developing into a stable form (Carlson et al. 1990), the number of calves for each year and location was derived from the number of individual mothers identified in the fluke catalogue. In order to obtain the denominator of the calculation, the number of calves was then added to the number of individual whales that had been identified, yielding the total number of individual whales for each year and location. Table 4 shows the annual crude birth rates, expressed in terms of calves per individual per year, for whales identified off Maui and the Big Island. The total number of individual whales from which each birth rate was calculated is shown in parentheses. Excluding sample sizes of less than 10, yearly birth rates in Maui varied from 0.012 in 1979 to 0.191 in 1986. For the Big Island, yearly birth rates varied from 0.000 in 1981 to 0.076 in 1990 .

As with calving rates, the mean of the annual birth rates does not truly represent the data because of small

Table 3. Megaptera novaeangliae. Annual calving rates (in parentheses total no. of females) in Hawailan waters. -: no data were collected for this location and year. "Some data were collected, but no females were seen

\begin{tabular}{|ccccccccccccccccccccccc}
\hline Location & 1977 & 1978 & 1979 & 1980 & 1981 & 1982 & 1983 & 1984 & 1985 & 1986 & 1987 & 1988 & 1989 & 1990 & 1991 & 1992 & 1993 & 1994 & Overall \\
\hline Maui & 0 & 0.67 & 0.50 & 1.0 & 0.75 & 0.70 & 0.81 & 0.53 & 1.0 & 1.0 & 0.55 & 0.80 &. & - & - & - & - & - & 0.71 \\
& $(1)$ & $(3)$ & $(2)$ & $(2)$ & $(8)$ & $(10)$ & $(16)$ & $(19)$ & $(2)$ & $(10)$ & $(11)$ & $(5)$ & & & & & \\
Big Island - & - & - & 0.33 & 0 & - & - & - & $\cdot$ & 0.60 & - & 0.20 & 0.60 & 0.63 & 0.29 & 0.67 & 0.67 & 0.80 & 0.52 \\
& & & $(3)$ & $(3)$ & & & & & $(5)$ & & $(5)$ & $(10)$ & $(8)$ & $(7)$ & $(6)$ & $(9)$ & $(5)$ & $(61)$ \\
\hline
\end{tabular}


Table 4. Megaptera novaeangliae. Annual crude birth rates (in parentheses total no. of whales, including calves) in Hawaiian waters. -: no data were collected for this location and year

\begin{tabular}{|lccccccccccccccccccc}
\hline Location & 1977 & 1978 & 1979 & 1980 & 1981 & 1982 & 1983 & 1984 & 1985 & 1986 & 1987 & 1988 & 1989 & 1990 & 1991 & 1992 & 1993 & 1994 & Overall \\
\hline Maui & 0 & 0.121 & 0.012 & 0.028 & 0.046 & 0.115 & 0.108 & 0.094 & 0.115 & 0.191 & 0.127 & 0.122 & 0 & - & - & - & - & - & 0.099 \\
& $(9)$ & $(33)$ & $(81)$ & $(106)$ & $(153)$ & $(157)$ & $(251)$ & $(254)$ & $(26)$ & $(89)$ & $(252)$ & $(139)$ & $(1)$ & & & & \\
\multirow{2}{*}{ Big Island -} & - & 0 & 0.015 & 0 & - & - & - & 0.063 & 0.057 & - & 0.039 & 0.065 & 0.076 & 0.058 & 0.070 & 0.074 & 0.065 & 0.061 \\
& & & $(1)$ & $(68)$ & $(54)$ & & & & $(16)$ & $(87)$ & & $(307)$ & $(293)$ & $(342)$ & $(311)$ & $(244)$ & $(392)$ & $(232)$ & $(2347)$ \\
\hline
\end{tabular}

sample sizes in some years. Excluding years in which less than 10 whales were identified, the mean birth rate for Maui was 0.098 (SE =0.015) and for the Big Island was $0.053(\mathrm{SE}=0.007)$. The overall birth rate, calculated by dividing the total number of calves by the total number of individual whales (including calves), is more representative of all available data. The overall birth rate was higher for Maui (0.099) than for the Big Island $(0.061)$. The proportion of individuals that were calves in Maui significantly exceeded the proportion at the Big Island (Yates corrected $\chi_{1}{ }^{2}=$ $18.40, p=0.001$ ). When all data from both locations were combined, the overall crude birth rate was 0.076 .

\section{DISCUSSION}

The results of this study suggest that the waters off west Maui are more highly utilised by mothers with their calves than are the waters off the northwest coast of the Big Island: individual females were more likely to be accompanied by calves off Maui than off the Big Island, and calves formed a greater proportion of the population in Maui waters than in the waters of the Big Island. Thus, it appears that the distribution of female humpback whales in Hawaiian waters depends, in part, upon reproductive status. Caution should be exercised, therefore, before attempting to generalise on the basis of reproductive data from a single sub-region of the winter grounds. Our findings of differences in habitat preferences are unlikely to be a result of differences in sampling technique between the 2 locations because the same data collection protocol was followed in both. There were differences in the timing of data collection in each location, such that many of the Big Island data were collected in more recent years than were Maui data. This raises the possibility that the results could have been influenced by an overall decline in reproductive rates across time. However, the regression of crude birth rate on year (Table 4 ) shows a positive slope for both the Big Island $(y=0.005 x-0.368, p=0.0002)$ and Maui $(y=0.006 x-0.405, p=0.1942)$. The positive slope, although not significant in the case of Maui, argues against a decline in birth rates. Moreover, aerial surveys throughout the main Hawaiian Islands have revealed that the overall population size and numbers of calves have increased over time, and that calf sightings have increased significantly off the Big Island (Mobley et al. 1999). Thus, the results reported here are unlikely to be due to temporal rather than geographical trends.

Previously reported birth rates are generally very close to the overall birth rate $(0.076)$ reported here. For example, a total of 302 whales, 22 of which were calves, were seen during aerial surveys of the Hawaiian Islands in 1976 (Herman \& Antinoja 1977, their Table 2), yielding a birth rate of 0.073 . Likewise, Clapham \& Mayo $(1987,1990)$ reported mean birth rates of 0.075 and 0.079 for the Gulf of Maine. However, the Maui birth rate (0.099) reported here is substantially higher than these values, and the Big Island rate $(0.061)$ is somewhat lower.

The calving rate of 0.58 calves per female per year in Hawaii reported by Baker et al. (1987) falls between the overall calving rate $(0.63)$ and the Big Island rate (0.52) presented here, but is considerably lower than the Maui rate $(0.71)$. A calving rate of 0.71 is higher than would be predicted from the assumption that mature female humpbacks reproduce, most commonly, every 2 yr (e.g. Chittleborough 1958, Clapham \& Mayo 1990, Straley 1994, Barlow \& Clapham 1997). This supports the idea that females with calves are more highly represented in the population off West Maui than in the wintering population as a whole.

In general, estimated calving rates may be inflated because not all females in the population have been identified. Also, the calculation of calving and birth rates assumed that the presence or absence of a calf had no effect on the probability of capturing a female photographically. However, because it appears that not all females migrate to the reproductive areas each winter (Brown et al. 1995, Craig \& Herman 1997), the probability of capture may be higher in the years when a female has a calf. In any given year, therefore, some females who otherwise would contribute to the denominators of reproductive rate calculations are missing from the winter grounds. Consequently, estimates of reproductive rates for the winter grounds are likely to be biased upwards. This potential bias is likely to affect calving rates more than birth rates because the 
denominator of the calving-rate calculation includes known females only, whereas the denominator of the birth-rate calculation includes males and whales of unknown sex as well. Indeed, calving rates reported from the summer grounds are generally lower than those calculated for the winter grounds. For example, Baker et al. (1992) reported an overall calving rate of 0.36 calves per female per year in southeastern Alaska, and Clapham \& Mayo (1990) reported a mean of 0.41 calves per mature female per year for humpbacks in the Gulf of Maine. This discrepancy between calving rates from feeding areas and those from wintering areas may be due in part to calf mortalities before arrival in the summer grounds, but at the same time, a greater percentage of the female population is likely to be present and therefore identified in the summer grounds than in the winter grounds.

There are no previously published studies comparing long-term reproductive data collected in more than 1 location within any humpback winter ground. However, the present results are consistent with earlier aerial surveys of the Hawaiian Islands showing that calves were more numerous within the Maui region than in the waters off the Big Island (Herman et al. 1980). Further support comes from shore-based observations of humpbacks in Maui and the Big Island. In 1987 and 1988, KBMML personnel collected data from 2 elevated shore stations on Maui and from 2 on the Big Island (see Helweg \& Herman 1994 for details). The shore-based research teams used high-powered optics to determine the composition of all pods within $6.5 \mathrm{~km}$ of the observational platform. In contrast to photoidentification data, these data did not depend upon obtaining fluke photographs of the mother. A re-examination of the data presented by Helweg (1989, Tables 13 to 16$)$ showed that 53 of $588(9.0 \%)$ whales observed at Maui were calves, but only 25 of $480(5.2 \%)$ whales observed at the Big Island were calves (Yates corrected $\left.\chi_{1}{ }^{2}=5.10, p=0.024\right)$. These shore station results are close to the results reported here for each region, based on photographic identification data.

Although there have been no comparisons of longterm data collected from different areas within the winter grounds of the North Atlantic, data from ship-based surveys have suggested that calves are not distributed evenly throughout the West Indies (Whitehead \& Moore 1982, Mattila \& Clapham 1989). However, humpback whale densities as a whole vary throughout this region, and it is not clear if the nronortion of calves relative to adults varies across sub-regions.

Our results show that there was considerable interchange between the Big Island and Maui across years: more than half the females were identified in both locations in different years. Darling \& McSweeney (1985) reported that $33 \%$ of humpback whales identi- fied off the Big Island between 1978 and 1981 were also identified off Maui between 1977 and 1981, but the sex of these whales was not reported. However, Cerchio et al. (1998) reported that between 1989 and 1991, only 40 of 1072 whales identified at Kauai and the Big Island were identified in both locations, and of these, only 1 was known to be female. The Big Island is much closer to Maui than to Kauai, and it is possible that females move more commonly between the Big Island and Maui than they do between the Big Island and Kauai. However, the present study is based on considerably more seasons (18) than were analysed by Cerchio et al. (3), and it is probable that many more female movements would have been documented between Kauai and the Big Island had the sample size been larger.

Baker \& Herman (1981) suggested that temporal differences in peaks of abundance reported for different regions within Hawaii may be due to differences in habitat preference by different classes of whale. As was noted, these authors reported that the peak of humpback abundance occurs later in the Maui region than off the Big Island. In this connection, it is interesting to note that, based on whaling data, late-pregnant females are the last class of whales to arrive at the winter grounds (Dawbin 1966, Nishiwaki 1966). If, as the present results suggest, Maui is a more favoured habitat for mothers than is the Big Island, the peak of abundance in Maui may coincide with an influx of females with calf as a result of temporal segregation during migration from the summer grounds. Similarly, the peak of abundance at the Big Island may occur before the arrival of females with calf; or, it may be that this peak occurs before the majority of calves are born. It is also possible that the early departure of whales from the Big Island (Herman et al. 1980) is a result of the 'migratory parade' described by Dawbin (1966): if females without calves are more prevalent off the Big Island than off Maui and newly pregnant females are among the first whales to leave the winter grounds, the early departure of these females will have a greater effect on whale density in Big Island waters than in the waters off Maui.

Little is known about the factors influencing habitat usage by humpback whales in the winter grounds. It is possible that undersea topography has some influence on habitat choice. Humpbacks in Hawaii are found principally in waters less than $183 \mathrm{~m}$ (100 fathoms) deep (Herman \& Antinoja 1977, Herman et al. 1980, Mobley et al. 1997). The bathymetric features of the 2 study areas appear to be relatively distinct: almost the entire area between west Maui and the islands of Lanai and Kahoolawe is less than $183 \mathrm{~m}$ deep (see Fig. 1), whereas off the northwest coast of the Big Island the $183 \mathrm{~m}$ isobath is generally within $5 \mathrm{~km}$ of 
the coastline, and depth increases rapidly. Smultea (1994) reported that off the northwest coast of the Big Island, groups containing a calf were found in shallower water than were groups without a calf. She suggested that females with calves may use shallow water to provide protection from potential predators such as deep-water sharks, or to minimise harassment from sexually active males. The finding that females accompanied by a calf are more prevalent off west Maui than off the northwest coast of the Big Island may thus be due to a preference of females with calves for extensive shallow waters. However, other factors as yet unknown may also contribute to the apparent difference in habitat utilisation. Clearly, further research is required to clarify the determinants of humpback whale habitat usage in the winter grounds.

Acknowiedgements. We are grateful to numerous staff members, students and Earthwatch volunteers who have contributed to the KBMML data set over the years, and thank them all for their hard work and dedication. Funding for data collection was provided by the Center for Field Research (Earthwatch), Sea Grant of the University of Hawaii, the National Science Foundation and the National Marine Fisheries Service. Facilities for report presentation were provided by The Dolphin Institute. We thank Phil Clapham and 3 anonymous reviewers for comments on an earlier version of this manuscript.

\section{LITERATURE CITED}

Baker CS, Herman LM (1981) Migration and local movement of humpback whales (Megaptera novaeangliae) through Hawaijan waters. Can J Zool 59:460-469

Baker CS, Herman LM (1987) Alternative population estimates of the humpback whale (Megaptera novaeangliae) in Hawaiian waters. Can J Zool 65:2818-2821

Baker CS, Perry A, Herman LM (1987) Reproductive histories of female humpback whales Megaptera novaeangliae in the North Pacific. Mar Ecol Prog Ser 41:103-114

Baker CS, Straley JM, Perry A (1992) Population characteristics of individually identified humpback whales in southeastern Alaska: summer and fall 1986. Fish Bull US 90: 429-437

Barlow J, Clapham PJ (1997) A new birth interval approach to estimating demographic parameters of humpback whales. Ecology 78:535-546

Brown MR, Corkeron PJ, Hale PT, Schultz KW, Bryden MM (1995) Evidence for a sex-segregated migration in the humpback whale (Megaptera novaeangliae). Proc R Soc Lond B Biol Sci 259:229-234

Carlson CA, Mayo CA, Whitehead H (1990) Changes in the ventral fluke pattern of the humpback whale (Megaptera novaeangliae) and its effect on matching; evaluation of its significance to photo-identification research. Rep Int Whaling Comm Spec Issue 12:105-111

Cerchio S, Gabriele CM, Norris TF, Herman LM (1998) Movements of humpback whales between Kauai and Hawaii: implications for population structure and abundance estimation in the Hawaiian Islands. Mar Ecol Prog Ser 175:13-22

Chittleborough RG (1958) The breeding cycle of the female humpback whale, Megaptera novaeangliae (Borowski). Aust J Mar Freshw Res 9:1-18

Chittleborough RG (1965) Dynamics of two populations of the humpback whale Megaptera novaeangliae (Borowski). Aust J Mar Freshw Res 16:33-128

Clapham PJ, Mayo CA (1987) Reproduction and recruitment of individually identified humpback whales, Megaptera novaeangliae, observed in Massachusetts Bay, 1979-1985. Can J Zool 65:2853-2863

Clapham PJ, Mayo CA (1990) Reproduction of humpback whales (Megaptera novaeangliae) observed in the Gulf of Maine. Rep Int Whaling Comm Spec Issue 12:171-1.75

Craig AS, Herman LM (1997) Sex differences in site fidelity and migration of humpback whales (Megaptera novaeangliae) to the Hawaiian Islands. Can J Zool 75:1923-1933

Darling JD, MCSweeney DJ (1985) Observations on the migrations of North Pacific humpback whales (Megaptera novaeangliae). Can J Zool 63:308-314

Darling JD, Morowitz H (1986) Census of 'Hawaiian' humpback whales (Megaptera novaeangliae) by individual identification. Can J Zool 64:105-111

Dawbin WH (1966) The seasonal migratory cycle of humpback whales. In: Norris KS (ed) Whales, dolphins, and porpoises. University of California Press, Berkeley, $p$ 145-170

Frankel AS, Clark CW, Herman LM, Gabriele CM (1995) Spatial distribution, habitat utilization, and social interactions of humpback whales, Megaptera novaeangliae, off Hawaii, determined using acoustic and visual techniques. Can J Zool 73:1134-1146

Glockner DA, Venus SC (1983) Identification, growth rate and behavior of humpback whale (Megaptera novaeangliae) cows and calves in the waters off Maui, Hawaii, 1977-1979. In: Payne RS (ed) Communication and behavior of whales. Westriew Press, Boulder, CO, p 223-258

Glockner-Ferrari DA, Ferrari MJ (1990) Reproduction in the humpback whale (Megaptera novaeangliae) in Hawaiian waters, 1975-1988: the life history, reproductive rates and behavior of known individuals identified through surface and underwater photography. Rep Int Whaling Comm Spec Issue 12:161 $\rightarrow 169$

Helweg DA (1989) The daily and seasonal patterns of behavior and abundance of humpback whales (Megaptera novaeangliae) in Hawaiian waters. MA thesis, University of Hawaii, Honolulu, HI

Helweg DA, Herman LM (1994) Diurnal patterns of behaviour and group membership of humpback whales (Megaptera novaeangliae) wintering in Hawaiian waters. Ethology 98:298-311

Herman LM (1979) Humpback whales in Hawaiian waters: a study in historical ecology. Pac Sci 33:1-15

Herman LM, Antinoja RC (1977) Humpback whales in the Hawaiian breeding waters: population and pod characteristics. Sci Rep Whales Res Inst Tokyo 29:59-85

Herman LM, Forestell PH, Antinoja RC (1980) The 1976/77 migration of humpback whales into Hawaiian waters: composite description. Rep No. MMC-77/19, Marine Mammal Commission, Washington, DC

Katona S, Baxter B, Brazier O, Kraus S, Perkins J, Whitehead $H$ (1979) Identification of humpback whales by fluke photographs. In: Winn HE, Olla BL (eds) Behavior of marine animals, Vol 3. Cetaceans. Plenum Press, New York, p 33-44

Mattila DK, Clapham PJ (1989) Humpback whales, Megaptera novaeangliae, and other cetaceans on Virgin Bank and in the northern Leeward Islands, 1985 and 1986. Can J Zool 67:2201-2211

Mobley JR Jr, Forestell PH. Grotefendt RA (1997) Preliminary results of 1993 and 1995 aerial surveys of Hawaiian wa- 
ters. In: Payne PM, Phillips B, Nitta ET (eds) Report of the workshop to assess research and other needs and opportunities related to humpback management in the Hawaiian Islands. NOAA Technical Memorandum NMFS-OPR-11, US Department of Commerce, Seattle, WA, p 1-8

Mobley JR Jr, Bauer GB, Herman LM (1999) Changes over a ten-year interval in the distribution and relative abundance of humpback whales (Megaptera novaeangliae) wintering in Hawaiian waters. Aquat Mamm 25:63-72

Nishiwaki M (1959) Humpback whales in Ryukyuan waters. Sci Rep Whales Res Inst Tokyo 15:1-15

Nishiwaki $M$ (1966) Distribution and migration of the larger cetaceans in the North Pacific as shown by Japanese whaling results. In: Norris KS (ed) Whales, dolphins, and porpoises. University of California Press, Berkeley, p 171-191

Perry A, Mobley JR, Baker CS, Herman LM (1988) Humpback whales of the Central and Eastern North Pacific: a catalog of individual identification photographs. Sea Grant Mis-

Editorial responsibility: Otto Kinne (Editor),

Oldendorf/Luhe, Germany cellaneous Rep UNIHI-SEAGRANT-MR-88-02, Honolulu, HI

Perry A, Baker CS, Herman LM (1990) Population characteristics of individually identified humpback whales in the central and eastern North Pacific: a summary and critique. Rep Int Whaling Comm Spec Issue 12:307-317

Smultea MA (1994) Segregation by humpback whale (Megaptera novaeangliae) cows with calves in coastal habitat near the island of Hawaii. Can J Zool 72:805-811

Straley JM (1994) Seasonal characteristics of humpback whales (Megaptera novaeangliae) in southeastern Alaska. MS thesis, University of Alaska, Fairbanks

Tomilin AG (1967) Mammals of the USSR and adjacent countries, Vol. IX. Cetacea. Translated by O Ronen, Israeli Program for Scientific Translations, Jerusalem

Whitehead H, Moore MJ (1982) Distribution and movements of West Indian humpback whales in winter. Can J Zool 60 : $2203-2211$

Submitted: May 20, 1999; Accepted: September 6, 1999 Proofs received from author(s): February 4, 2000 